\title{
UJI EFEK EKSTRAK ETANOL DAUN SUKUN (Artocarpus altilis (Parkinson Ex F.A.Zorn) TERHADAP PENURUNAN KADAR GLUKOSA DARAH, KOLESTEROL TOTAL DAN GAMBARAN HISTOPATOLOGI PANKREAS TIKUS PUTIH JANTAN (Rattus norvegicus) HIPERKOLESTEROLEMIA- DIABETES
}

\author{
Joni Tandi*, Moh Rizky, Rio Mariani, Fajar Alan \\ Program Studi S1 Farmasi STIFA Pelita Mas Palu \\ *Corresponding author email : stifapelitamaspalu@yahoo.com
}

\begin{abstract}
ABSTRAK
Penelitian ini bertujuan untuk mengetahui efek serta dosis efektif ekstrak daun sukun dalam menurunkan kadar glukosa darah, kolesterol total dan gambaran histopatologi pangkreas pada hewan uji tikus putih jantan model hiperkolesterolemia-diabetes yang diinduksi pakan tinggi lemak dan streptozotocin. Penelitian dilakukan menggunakan 35 ekor hewan uji yang dikelompokkan dalam 7 kelompok dengan perlakuan yaitu kelompok kontrol normal, kontrol negatif, kontrol positif metformin, kelompok positif sinvastatindan 3 kelompok uji dengan variasi dosis ekstrak masing-masing $100 \mathrm{mg} / \mathrm{KgBB}, 200 \mathrm{mg} / \mathrm{KgBB}$, dan 400 $\mathrm{mg} / \mathrm{KgBB}$. Pengukuran kadar glukosa darah dan kadar olesterol dilakukan pada hari ke 0, 35, 42, dan 49 setelah diberi perlakuan. Data kadar glukosa darah dan kolesterol total yang diperoleh dianalisis menggunakan uji one way ANOVA pada taraf kepercayaan 95\% dan dilanjutkan dengan uji Post Hoc LSD, dan data hasil skoring tingkat kerusakan pankreas dianalisis dengan uji Kruskal-Wallis dilanjutkan dengan uji Mann-Whitney untuk melihat perbedaan antar perlakuan. Hasil penelitian menunjukkan bahwa terdapat senyawa metabolit sekunder pada ekstrak etanol sukun, ekstrak daun sukun dengan dosis efektif 200 $\mathrm{mg} / \mathrm{kgBB}$ memiliki efek terhadap kadar glukosa darah dan kadar kolesterol total, dosis $400 \mathrm{mg} / \mathrm{kgBB}$ regenerasi jaringan pankreas tikus.
\end{abstract}

Kata Kunci : Daun sukun (Artocarpus altilis (Parkinson Ex F.A.Zorn) Fosberg), antihiperglikemia, antihiperkolesterolemia, diabetes

Submitted on: 4 April $2017 \quad$ Accepted on: 7 May 2017

DOI: https://doi.org/10.25026/jsk.v1i8.73

\section{PENDAHULUAN}

Perkembangan zaman dan teknologi saat ini, banyak terjadi perubahan yang signifikan pada kehidupan manusia termasuk di Indonesia, terutama dalam memilih gaya hidup dan salah satunya adalah makanan. Saat ini makanan banyak menjadi penyebab penyakit-penyakit yang tergolong tidak bisa untuk disembuhkan, salah satunya diabetes melitus (Kannon, M Q. 2011). Diabetes melitus merupakan suatu kelompok penyakit metabolik dengan karakteristik hiperglikemia yang terjadi karena kelainan sekresi insulin, kerja insulin atau kedua-duanya (Chairunnisa R. 2012). Diabetes melitus dapat dibedakan atas diabetes melitus tipe 1 atau Insulin-Dependent. Diabetes Mellitus (IDDM) dan diabetes melitus tipe 2 atau Non Insulin-Dependent Diabetes Mellitus (NIDDM) (Marianne, et al. 2011).

Peningkatan metabolisme lemak menyebabkan terjadinya metabolisme lemak yang abnormal disertai endapan kolesterol pada dinding pembuluh darah sehingga timbul gejala aterosklerosis serta berkuranya protein dalam jaringan tubuh. 
Uji Efek Ekstrak Etanol Daun Sukun (Artocarpus altilis (Parkinson Ex F.A.Zorn) terhadap Penurunan Kadar Glukosa Darah, Kolesterol Total dan Gambaran Histopatologi Pankreas Tikus Putih Jantan (Rattus norvegicus) Hiperkolesterolemia-Diabetes

Penyakit diabetes melitus dapat menyebabkan masalah kesehatan serius yang disebabkan oleh gula darah tinggi (hiperglikemia) seperti hiperkolesterolemia, hiperkolesterolemia adalah suatu kondisi dimana meningkatnya konsentrasi kolesterol dalam darah yang melebihi nilai normal (Guyton AC., 2006.).

Pankreas merupakan organ kelenjar penting dalam tubuh yang terdiri dari jaringan eksokrin dan endokrin. Fungsi pankreas yaitu menghasilkan getah pankres yang mengandung enzim-enzim tripsinogen, amilase dan lipase. Enzim tersebut bercampur dengan bahan makanan di duodenum dan menjalankan fungsi pencernaan di dalam usus, bagian eksokrin terdiri atas sel asinar yang mensekresikan enzim melalui saluran ke duodenum. Sementara, bagian endokrin terdiri dari pulau-pulau Langerhans yang fungsinya menghasilkan hormon insulin yang kemudian diserap masuk ke dalam darah. Insulin di butuhkan untuk metabolisme karbohidrat, lemak dan protein. Adanya senyawa kimia yang masuk ke dalam tubuh dengan dosis tinggi dapat menghancurkan sel-sel pulau Langerhans. Kerusakan ini akan menyebabkan produksi insulin menurun mengakibatkan hiperglikemia (Mycek, Marry J, 2001).

Salah satu tanaman tradisional yang terdapat di Indonesia dan dapat digunakan sebagai obat adalah Tanaman sukun (Artocarpus altilis (Parkinson Ex F.A.Zorn) Fosberg).

Penelitian terdahulu yang dilakukan oleh Agustin L, dkk (2015) uji aktivitas antihiperglikemia ekstrak etanol daun sukun (Artocarpus altilis (parkinson ex f.a.zorn) fosberg) pada mencit swiss wistar jantan dengan metode uji toleransi glukosa menyatakan ekstrak daun sukun pada dosis $400 \mathrm{mg} / \mathrm{kg}$ BB mencit efektif menurunkan kadar glukosa darah pada mencit wistar di induksi Glukosa. Penelitian lain dilakukan oleh Dewi safitri, dkk (2016) menggunakan esktrak daun sukun dengan dosis $50 \mathrm{mg} / \mathrm{kgBB}$, $100 \mathrm{mg} / \mathrm{kgBB}$ dan $200 \mathrm{mg} / \mathrm{kgBB}$ dapat mengembalikan kadar kolesterol pada tikus putih jantan yang diinduksi pakan tinggi lemak.

Berdasarkan uraian di atas maka peneliti tertarik untuk melakukan penelitian lebih lanjut, untuk mengetahui efek pemberian ekstrak etanol daun sukun dan perbedaan dosis bertingkat ekstrak daun sukun terhadap kadar glukosa darah, kolesterol, dan regenerasi jaringan pankreas tikus putih jantan model hiperkolesterolemia-diabetes. Penelitian ini diharapkan dapat menjadi sumber informasi baru untuk masyarakat tentang khasiat daun sukun sehingga dapat dimanfaatkan secara optimal.

\section{METODE PENELITIAN}

\begin{abstract}
Alat
Batang pengaduk, Blender (Circuit breker), Cawan porselin, Erlenmeyer, Gelas kimia, Gelas ukur, Glukometer (Accu check), Glukotest strip test (Accu check), Mission Ultra cholesterol, kolesterol strip, gunting, Mikroskop Olympus Bx-51 seperangkat alat bedah Kandang hewan uji, Penangas air, Pipet tetes, seperangkat alat Rotary Vaccum Evaporator, Spuit injeksi, Spuit oral, Tabung reaksi, Timbangan analitik, dan Timbangan hewan.
\end{abstract}

\section{Bahan}

Air Suling, Amoniak, Asam klorida pekat P, Asam klorida 2N, Asam Sulfat, Daun Sukun, Etanol 96\%, Kertas saring, Kloroform, Larutan $\mathrm{FeCl}_{3}$, Larutan $\mathrm{NaCl} 10 \%$, Na-CMC, Pakan tinggi lemak, pakan standar, Pereaksi Dragendorff, Serbuk Magnesium P, Streptozotocin, tablet simvastatin, dan Tablet metformin. 
Uji Efek Ekstrak Etanol Daun Sukun (Artocarpus altilis (Parkinson Ex F.A.Zorn) terhadap Penurunan Kadar Glukosa Darah, Kolesterol Total dan Gambaran Histopatologi Pankreas Tikus Putih Jantan (Rattus norvegicus) Hiperkolesterolemia-Diabetes

\section{Pembuatan Suspensi Metformin}

Dosis metformin pada manusia dewasa adalah $500 \mathrm{mg}$ per hari, jika dikonversi pada tikus dengan berat $200 \mathrm{~g}$ adalah $0,018 \mathrm{mg}$, maka dosis metformin untuk tikus adalah $9 \mathrm{mg} / 200 \mathrm{~g}$ BB. Ditimbang serbuk tablet metformin yang setara dengan $360 \mathrm{mg}$ kemudian disuspensi dalam $\mathrm{Na} \mathrm{CMC} 0,5 \%$ hingga $100 \mathrm{~mL}$. Simvastatin diberikan dalam bentuk suspensi dengan $\mathrm{NaCMC}$ sesuai dosis pada manusia yaitu $10 \mathrm{mg}$ yang dikonversikan berdasarkan konversi Laurance dan Bacharach yaitu dosis untuk setiap $200 \mathrm{~g}$ BB tikus setara dengan 0,018 kali dosis manusia, sehingga dosis yang digunakan adalah $(0,18 \mathrm{mg})(200 \mathrm{~g}) \mathrm{BB}$ tikus.

\section{Pembuatan Ekstrak Etanol Daun Sukun}

Proses ekstraksi bahan dilakukan dengan cara maserasi dengan pelarut etanol $96 \%$. Serbuk daun Sukun ditimbang 500 gram, kemudian dimaserasi dengan pelarut etanol $96 \%$ sebanyak 3 liter selama 3 hari. Selama perendaman ekstrak tiap hari diaduk. Ekstrak kemudian disaring dengan menggunakan kertas saring sehingga larutan terpisah dari ampas (residu). Kemudian diremaserasi menggunakan pelarut etanol 96\% selama 2 hari. Hasil maserasi disaring menggunakan kertas saring. Filtrat yang diperoleh dipekatkan dengan menggunakan rotary evaporator pada suhu $60^{\circ} \mathrm{C}$ kemudian diuapkan diatas waterbath pada suhu $60^{\circ} \mathrm{C}$ untuk menghilangkan sisa-sisa pelarut yang masih terdapat pada ekstrak hingga diperoleh ekstrak kental daun sehingga menghasilkan ekstrak kental.

\section{Pembuatan larutan Streptozotocin}

Streptozotocin (STZ) ditimbang sebanyak 0,24 gram, kemudian dilarutkan ke dalam buffer sitrat $\mathrm{pH} \quad 4,5$ lalu diinduksikan pada tikus melalui intraperitoneal (ip). Dosis streptozotocinyaitu $30 \mathrm{mg} / \mathrm{kg} \mathrm{BB}$.

\section{Pembuatan pakan tinggi lemak}

Makanan tinggi lemak yang digunakan adalah pakan standar $(80 \%)$, lemak babi (15\%), dan kuning telur bebek (5\%). Pakan dibuat dengan cara memanaskan lemak babi hingga lemak babi menjadi minyak. Kemudian telur direbus hingga matang, dipisahkan kuning telur dengan putih telur. Pakan standar dicampurkan dengan kuning telur yang telah dihaluskan dan minyak lemak babi. Jumlah konsumsi makanan setiap harinya maksimum sebanyak 20 g/tikus dan diberikan selama 4 minggu

\section{Analisis Data}

Data hasil pengamatan yang diperoleh berupa kadar glukosa darah dan kadar kolesterol dianalisis secara statistik menggunakan analisis Anova satu arah (One Way Anova) pada taraf kepercayaan 95\%. Selanjutnya dilakukan uji lanjut Post hoc Least Significant Difference (LSD) untuk mengetahui dosis yang efektif. Data skoring kerusakan pulau langerhans pankreas, dianalisis secara statistik menggunakan non parametrik kruskal wallis test dan dilanjutkan dengan manwhitney test untuk mengetahui perbedaan antar semua kelompok perlakuan. Pengolahan data dilakukan dengan menggunakan program software SPSS 23. 
Uji Efek Ekstrak Etanol Daun Sukun (Artocarpus altilis (Parkinson Ex F.A.Zorn) terhadap Penurunan Kadar Glukosa Darah, Kolesterol Total dan Gambaran Histopatologi Pankreas Tikus Putih Jantan (Rattus norvegicus) Hiperkolesterolemia-Diabetes

\section{HASIL DAN PEMBAHASAN}

Tabel 1. Hasil Uji FitokimiaEkstrak Etanol Daun Sukun

\begin{tabular}{lc}
\hline \multicolumn{1}{c}{ Pengujian } & Hasil \\
\hline Uji Flavonoid & + \\
Uji Polifenol & + \\
Uji Saponin & + \\
Uji Alkaloid & + \\
Uji Tanin & + \\
\hline
\end{tabular}

Keterangan :

$(+)$ : mengandung golongan senyawa yang diuji

(-) : tidak mengandung golongan senyawa yang diuji

Tabel 2. Rerata Kadar Glukosa Darah Tikus Putih Jantan yang Diinduksi Streptozotocin dan Pakan Tinggi lemak

\begin{tabular}{cccccccc}
\hline \multirow{2}{*}{$\begin{array}{c}\text { Hari } \\
\text { ke- }\end{array}$} & $\begin{array}{c}\text { kontrol } \\
\text { normal }\end{array}$ & $\begin{array}{c}\text { Kontrol } \\
\text { negatif }\end{array}$ & $\begin{array}{c}\text { Kontrol } \\
\text { positif } \\
\text { (Metformin) }\end{array}$ & $\begin{array}{c}\text { Dosis 100 } \\
\mathrm{mg} / \mathrm{kgBB}\end{array}$ & $\begin{array}{c}\text { Dosis 200 } \\
\mathrm{mg} / \mathrm{kgBB}\end{array}$ & $\begin{array}{c}\text { Dosis 400 } \\
\mathrm{mg} / \mathrm{kgBB}\end{array}$ & $\mathrm{P}$ \\
\hline 0 & $96,4 \pm 3.3$ & $104.2 \pm 9.4$ & $95 \pm 3.5$ & $99.6 \pm 7.3$ & $98 \pm 8.4$ & $97 \pm 3.84$ & 0,440 \\
35 & $98.6 \pm 5.5$ & $402.4 \pm 31.3$ & $315.8 \pm 37.3$ & $350.6 \pm 22.78$ & $365 \pm 29.3$ & $368 \pm 73.5$ & 0,000 \\
42 & $99.6 \pm 3.00$ & $383.4 \pm 29.3$ & $117 \pm 3.16$ & $146.8 \pm 15.8$ & $136.6 \pm 6.8$ & $134.4 \pm 8.0$ & 0,000 \\
49 & $96.8 \pm 2.0$ & $360.6 \pm 29.3$ & $106.4 \pm 3.9$ & $119.8 \pm 12.3$ & $108.4 \pm 4.7$ & $110.4 \pm 7.1$ & 0,000 \\
\hline
\end{tabular}

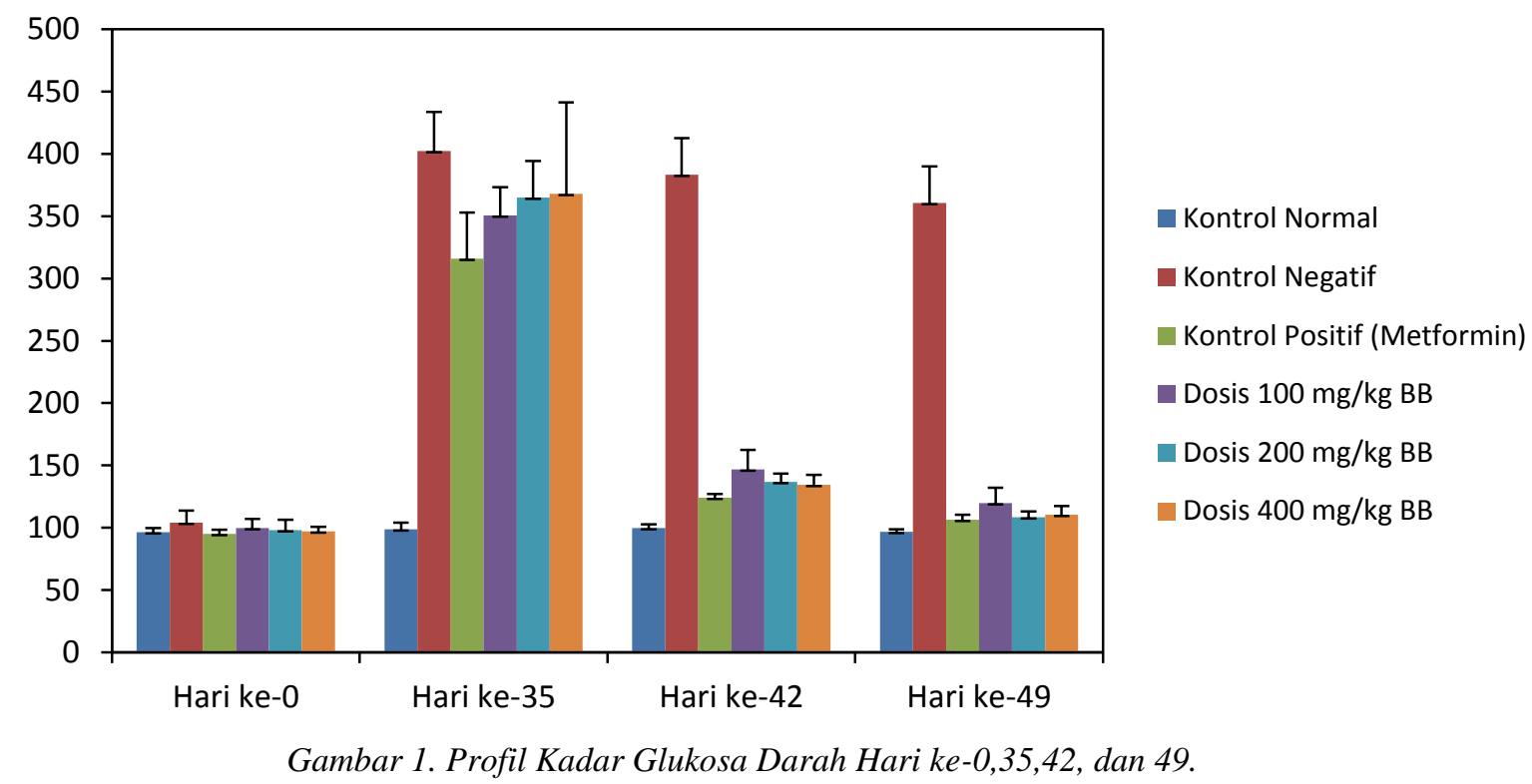


Uji Efek Ekstrak Etanol Daun Sukun (Artocarpus altilis (Parkinson Ex F.A.Zorn) terhadap Penurunan Kadar Glukosa Darah, Kolesterol Total dan Gambaran Histopatologi Pankreas Tikus Putih Jantan (Rattus norvegicus) Hiperkolesterolemia-Diabetes

Tabel 3. Rerata Kadar Kolesterol Tikus Putih Jantan yang Diinduksi Streptozotocin dan Pakan Tinggi lemak

\begin{tabular}{cccccccc}
\hline & \multicolumn{7}{c}{ Rerata \pm SD Kadar Kolestrol Total (mg/dL) } \\
\cline { 2 - 8 } ke- & $\begin{array}{c}\text { kontrol } \\
\text { normal }\end{array}$ & $\begin{array}{c}\text { Kontrol } \\
\text { negatif }\end{array}$ & $\begin{array}{c}\text { Kontrol } \\
\text { positif } \\
\text { (Metformin) }\end{array}$ & $\begin{array}{c}\text { Dosis 100 } \\
\mathrm{mg} / \mathrm{kgBB}\end{array}$ & $\begin{array}{c}\text { Dosis 200 } \\
\mathrm{mg} / \mathrm{kgBB}\end{array}$ & $\begin{array}{c}\text { Dosis 400 } \\
\mathrm{mg} / \mathrm{kgBB}\end{array}$ & $\mathrm{p}$ \\
\hline 0 & $103 \pm 2.6$ & $111.8 \pm 7.3$ & $107.8 \pm 7.6$ & $107.8 \pm 7.2$ & $104.2 \pm 6.0$ & $105 \pm 4.4$ & 0,399 \\
35 & $108.6 \pm 2.1$ & $280.2 \pm 5.6$ & $271 \pm 27.0$ & $273 \pm 27.7$ & $269.6 \pm 26.3$ & $269.4 \pm 17.9$ & 0,000 \\
42 & $109.4 \pm 4.3$ & $273 \pm 4.8$ & $203.8 \pm 12.0$ & $223.2 \pm 11.4$ & $211 \pm 11.6$ & $231.2 \pm 5.2$ & 0,000 \\
49 & $111.2 \pm 5.7$ & $265 \pm 5.5$ & $273.6 \pm 18.7$ & $198.2 \pm 11.6$ & $181.8 \pm 6.7$ & $213 \pm 4$ & 0,000 \\
\hline
\end{tabular}

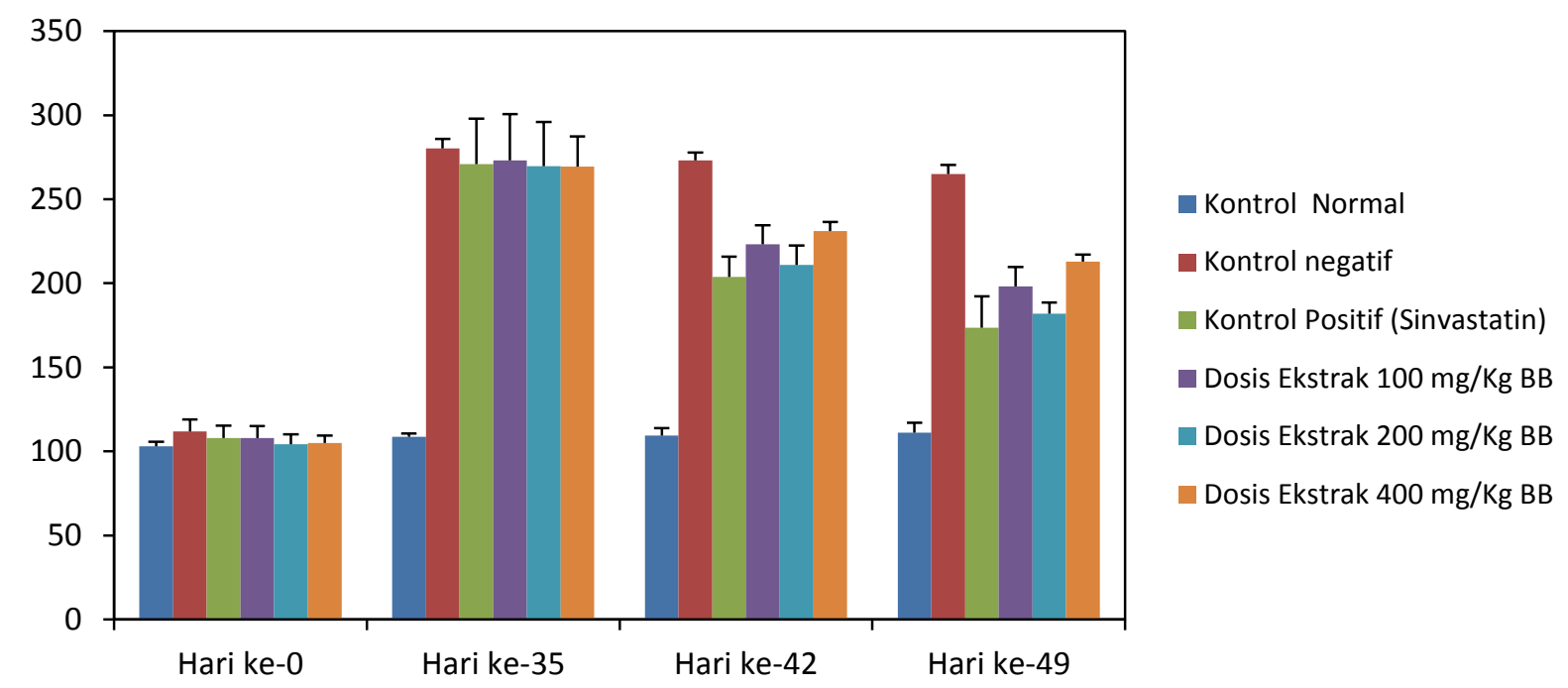

Gambar 2. Profil Kadar kolesterol Hari ke-0,35,42, dan 49.

Tabel 4. Hasil Skoring Pengamatan Preparat Histopatologi Pankreas

\begin{tabular}{|c|c|c|c|c|c|c|}
\hline \multirow{2}{*}{ Perlakuan } & \multicolumn{5}{|c|}{ Skor Histopatologi Pankreas Hewan Uji } & \multirow{2}{*}{ Rerata \pm SD } \\
\hline & 1 & 2 & 3 & 4 & 5 & \\
\hline Kontrol Normal (Na CMC 0,5\%) & 0 & 0 & 0 & 0 & 0 & $0 \pm 0$ \\
\hline Kontrol Negatif & 3 & 4 & 3 & 4 & 3 & $3,5 \pm 0,577$ \\
\hline Kontrol Positif & 0 & 0 & 0 & 1 & 0 & $1,75 \pm 0,5$ \\
\hline $\begin{array}{l}\text { Ekstrak Etanol Daun Sukun Dosis } \\
100 \mathrm{mg} / \mathrm{Kg} \mathrm{BB}\end{array}$ & 3 & 2 & 2 & 2 & 3 & $2 \pm 0$ \\
\hline $\begin{array}{l}\text { Ekstrak Etanol Daun Sukun Dosis } \\
200 \mathrm{mg} / \mathrm{Kg} \mathrm{BB}\end{array}$ & 2 & 2 & 1 & 1 & 0 & $2,25 \pm 0,5$ \\
\hline $\begin{array}{l}\text { Ekstrak Etanol Daun Sukun Dosis } \\
400 \mathrm{mg} / \mathrm{Kg} \mathrm{BB}\end{array}$ & 1 & 0 & 0 & 0 & 1 & $3,25 \pm 0,5$ \\
\hline
\end{tabular}

\section{Gambar Histopatologi Pankreas Tikus}

Skor kerusakan pankreas :

- Skor $0=$ Normal tidak ada perubahan dari batas organ P. Langerhans, jumlah sel, nekrotik sel dan bentuk sel. 
Uji Efek Ekstrak Etanol Daun Sukun (Artocarpus altilis (Parkinson Ex F.A.Zorn) terhadap Penurunan Kadar Glukosa Darah, Kolesterol Total dan Gambaran Histopatologi Pankreas Tikus Putih Jantan (Rattus norvegicus) Hiperkolesterolemia-Diabetes

- Skor 1 = Batas jelas, jumlah sel mulai berkurang, nekrotik sel blm terlihat hanya degenerasi sel, bentuk sel normal.

- Skor 2 = Batas mulai tidak jelas, jumlah sel berkurang, degenerasi sel dan bentuk sel ada yang tdk normal.

- Skor 3 = Batas tidak jelas, jumlah sel berkurang, nekrotik sel terlihat dan bentuk sel banyak tidak normal.

- Skor 4 = Batas sangat tidak jelas, jumlah sel banyak berkurang dan sel hampir keseluruhan nekrotik dan bentuk sel tidak normal.
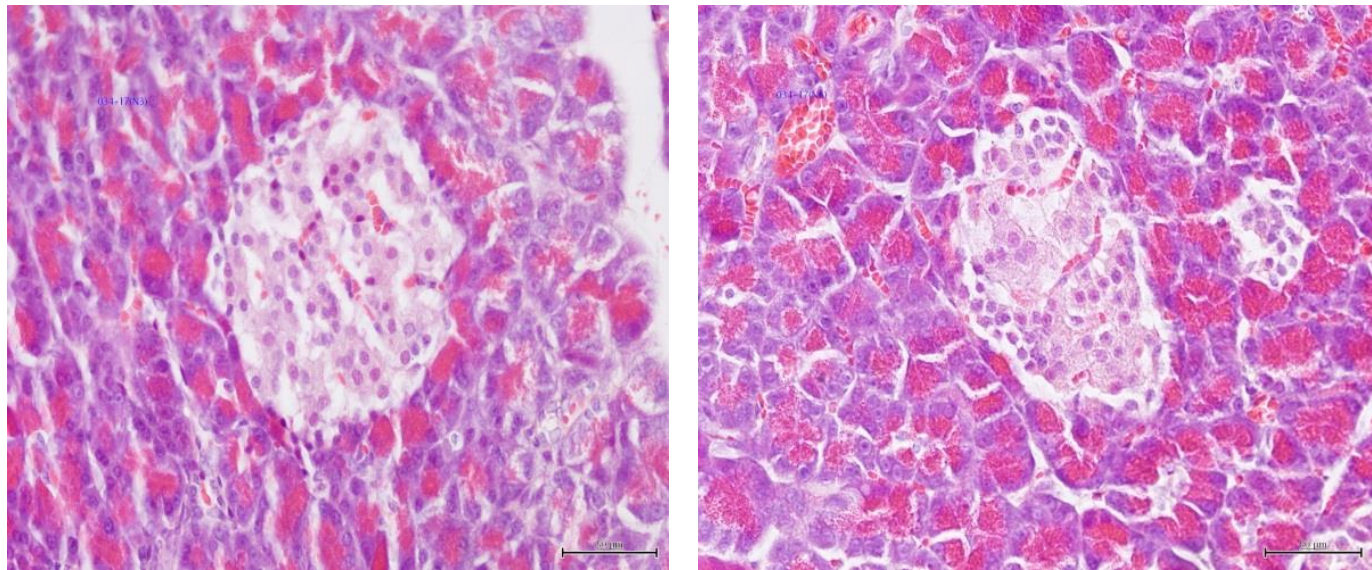

Gambar 3. Histopatologi jaringan pankreas Tikus Skor O (perbesaran 400x, pewarnaan HE)

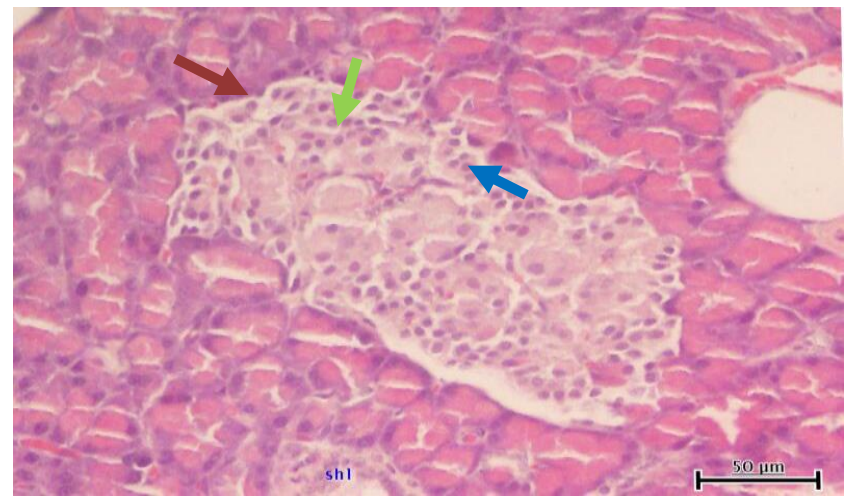

Gambar 4. Histopatologi jaringan pankreas Tikus Skor 1 (perbesaran 400x, pewarnaan HE)

Keterangan : Pulau langerhans dengan tingkat nekrosis yang paling ringan 1-25\%. batas jelas (merah), jumlah sel mulai berkurang (biru), nekrotik sel blm terlihat hanya degenerasi sel, bentuk sel normal (hijau). 
Uji Efek Ekstrak Etanol Daun Sukun (Artocarpus altilis (Parkinson Ex F.A.Zorn) terhadap Penurunan Kadar Glukosa Darah, Kolesterol Total dan Gambaran Histopatologi Pankreas Tikus Putih Jantan (Rattus norvegicus) Hiperkolesterolemia-Diabetes
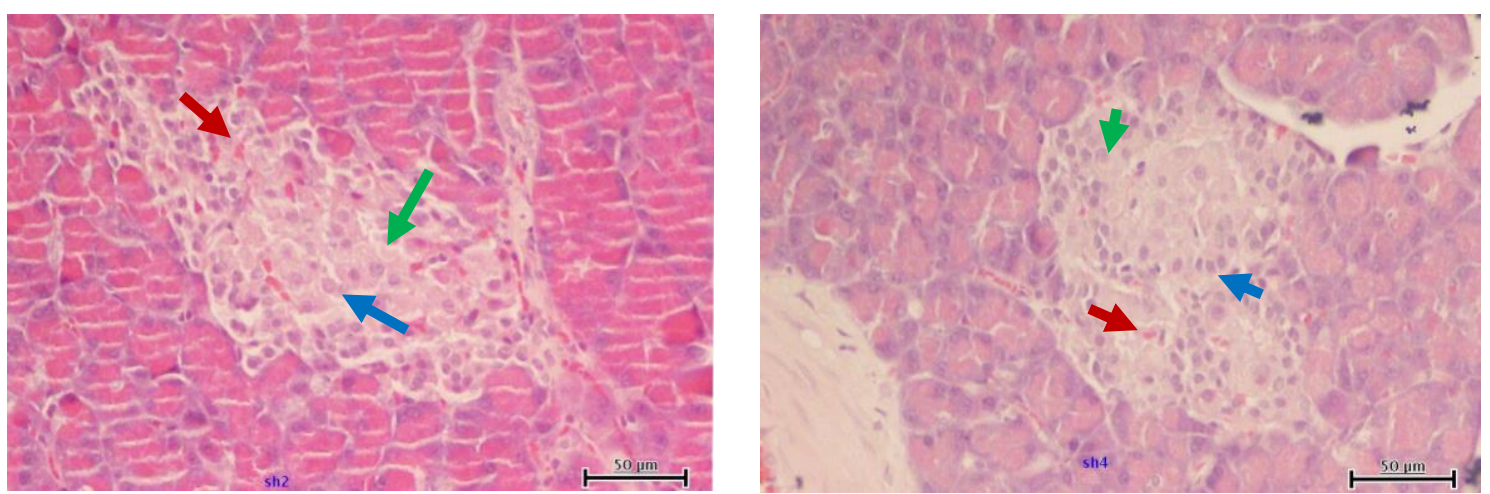

Gambar 5. Histopatologi jaringan pankreas Tikus Skor 2 (perbesaran 400x, pewarnaan HE)

Keterangan : Pulau langerhans dengan tingkat nekrosis 25-50\%, pada gambar di atas batas sel mulai tidak jelas (merah), jumlah sel berkurang (biru), degenerasi sel dan bentuk sel ada yang tdk normal (hijau)
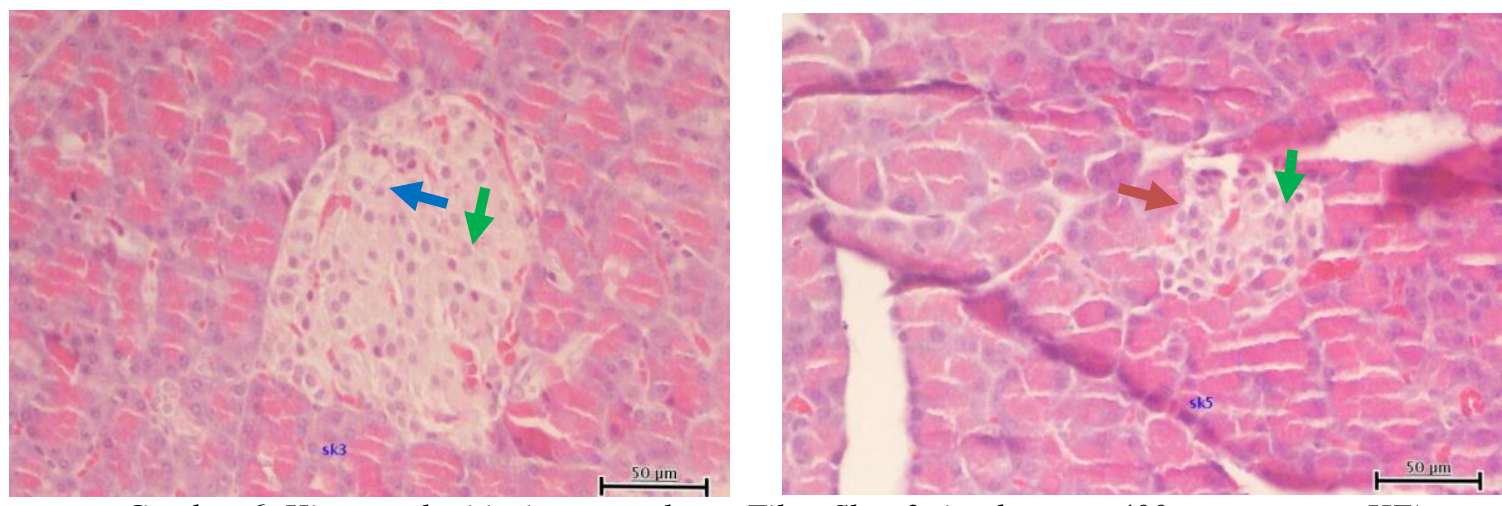

Gambar 6. Histopatologi jaringan pankreas Tikus Skor 3 (perbesaran 400x, pewarnaan HE)

Keterangan : Pulau langerhans dengan tingkat nekrosis 50-75\%, pada gambar di atas batas tidak jelas (merah), jumlah sel berkurang (biru), nekrotik sel terlihat dan bentuk sel banyak tidak normal (hijau).
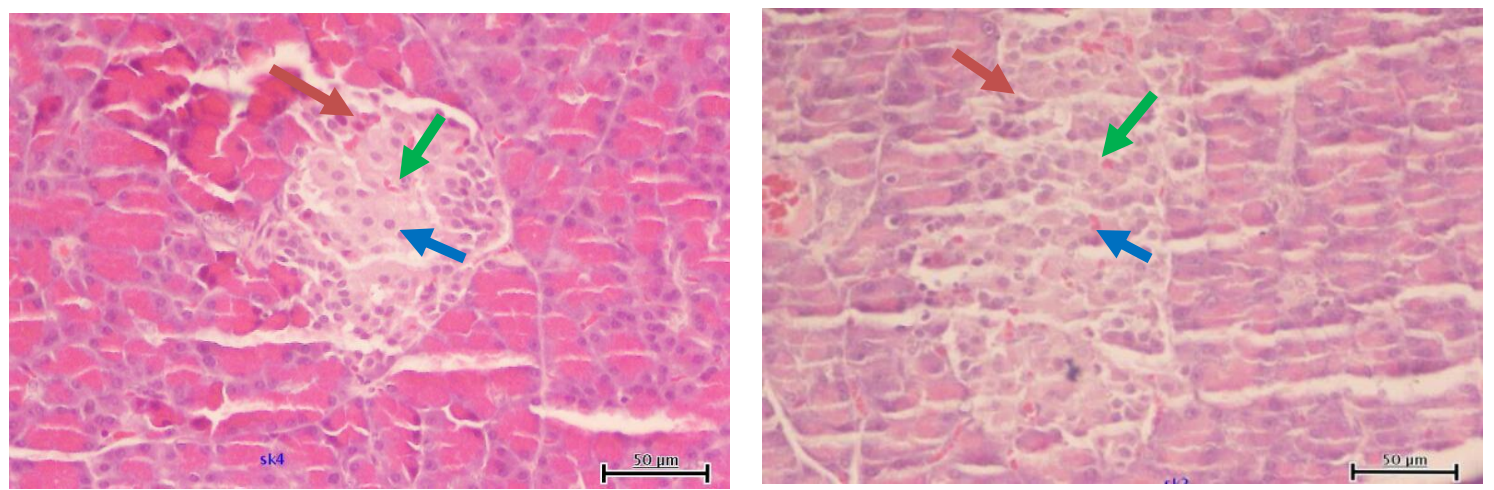

Gambar 7 Histopatologi jaringan pankreas Tikus Skor 4 (perbesaran 400x, pewarnaan HE)

Keterangan : Pulau langerhans dengan tingkat nekrosis $>75 \%$, pada gambar di atas batas sangat tidak jelas (merah), jumlah sel banyak berkurang (biru) dan hampir keseluruhan nekrotik dan bentuk sel tidak normal (hijau). 
Uji Efek Ekstrak Etanol Daun Sukun (Artocarpus altilis (Parkinson Ex F.A.Zorn) terhadap Penurunan Kadar Glukosa Darah, Kolesterol Total dan Gambaran Histopatologi Pankreas Tikus Putih Jantan (Rattus norvegicus) Hiperkolesterolemia-Diabetes

\section{Pembahasan}

Penelitian ini menggunakan daun sukun (Artocarpus altilis (Parkinson Ex F.A.Zorn) Fosberg) yang diperoleh di Kota Palu Sulawesi Tengah. Sebelumnya telah dilakukan determinasi tanaman di UPT. Sumber Daya Hayati Universitas Tadulako Sulawesi Tengah. Hasil determinasi tanaman menunjukkan bahwa yang digunakan adalah benar sukun (Artocarpus altilis (Parkinson Ex F.A.Zorn) Fosberg).

Penelitian ini menggunakan hewan uji berupa tikus putih jantan (Rattus norvegicus L.) sebanyak 30 ekor. Penggunaan tikus putih jantan sebagai hewan uji karena dapat memberikan hasil penelitian yang lebih stabil karena tidak dipengaruhi oleh siklus estrus dan kehamilan seperti pada tikus putih betina. Tikus putih jantan juga mempunyai kecepatan metabolisme obat yang lebih cepat dan kondisi biologis tubuh yang lebih stabil dibanding tikus betina (Kusumawati, D. 2004). Semua hewan uji kemudian di ukur kadar awal glukosa darah sebelum diberikan pakan lemak tinggi kolesterol dan induksi streptozotocin. Hasil pengukuran kadar glukosa darah awal yaitu berkisar antara 83-116 mg/dL. Hal ini menunjukkan seluruh tikus memiliki kadar glukosa darah normal. kadar glukosa darah normal tikus wistar berkisar antara 50-135 mg/dL (Kusumawati, D. 2004). Kemudian 5 kelompok tikus kecuali kelompok normal diberikan pakan lemak tinggi kolesterol dengan komposisi pakan standar (80\%), lemak babi (15\%), dan kuning telur bebek (5\%) selama 4 minggu. Pemberian pakan lemak tinggi kolesterol bertujuan untuk meningkatkan kandungan asam lemak bebas di dalam plasma sel yang dapat mengganggu sensitivitas insulin pada jaringan perifer. Kemudian hewan uji diinjeksikan streptozotocin dosis rendah (30 $\mathrm{mg} / \mathrm{KgBB}$ ) bertujuan untuk menaikan kadar glukosa darah. Penyebab hiperglikemia yang kronik sesudah pemberian streptozotocin adalah nekrosis sel beta pankreas (Nurdiana, P,N. Setyawati, M,A. 1998). Hasil pengukuran setelah pemberian induksi streptozotocin mengalami peningkatan yang signifikan antara 243-473 $\mathrm{mg} / \mathrm{dL}$ yang menunjukkan seluruh tikus mengalami kondisi diabetes (tikus dinyatakan diabetes apabila kadar glukosa darah > $200 \mathrm{mg} / \mathrm{dL}$ ). Hewan uji yang hiperglikemia diberikan perlakuan selama 7 hari hingga 14 hari. Pemberian perlakuan selama 7 hari dan 14 hari dilakukan untuk melihat efek penurunan kadar glukosa darah pada pemberian jangka pendek dan jangka panjang. Pengukuran kadar glukosa darah pada hari ke-42 untuk melihat efek jangka pendek penurunan kadar glukosa darah. Hasil pengukuran menunjukkan kadar glukosa darah berkisar 113-168 $\mathrm{mg} / \mathrm{dL}$. Hasil pengukuran kadar glukosa darah puasa pada perlakuan yang diberikan ekstrak daun sukun masih menunjukkan kadar glukosa darah diatas $126 \mathrm{mg} / \mathrm{dL}$. Oleh karena itu perlakuan dilanjutkan hingga hari ke-49 untuk melihat efek jangka panjang penurunan kadar glukosa darah. Hasil pengukuran menunjukkan kadar glukosa darah mengalami penurunan antara 102-144 mg/dL. Dalam hal ini terlihat bahwa efek penurunan kadar glukosa darah yang diberikan metformin mempunyai efek yang cepat dibandingkan ekstrak daun sukun. Hal ini dikarenakan efek dari obat kimia lebih cepat dibanding obat tradisional (Puersul, dkk. 2007).

Data hasil pengamatan kadar glukosa darah dan kolesterol tikus kemudian dianalisis secara statistik. Pengujian statistik hasil pengukuran kadar glukosa darah dan kolesterol kelompok hewan uji pada hari ke-0, 35, 42, dan 49 dilakukan dengan analisis Anova satu arah (One Way Anova) dan dilanjutkan dengan uji lanjut Post hoc Duncan (LSD). Hasil statistik One Way Anova pada hari ke-0 memperlihatkan nilai $\mathrm{P}=0,531 \quad(\mathrm{P}>0,05)$ yang menunjukkan tidak terdapat perbedaan yang signifikan pada semua 
Uji Efek Ekstrak Etanol Daun Sukun (Artocarpus altilis (Parkinson Ex F.A.Zorn) terhadap Penurunan Kadar Glukosa Darah, Kolesterol Total dan Gambaran Histopatologi Pankreas Tikus Putih Jantan (Rattus norvegicus) Hiperkolesterolemia-Diabetes

kelompok perlakuan yaitu kontrol normal, kontrol negatif, kontrol positif, dosis 100 $\mathrm{mg} / \mathrm{Kg} \mathrm{BB}, 200 \mathrm{mg} / \mathrm{Kg} \mathrm{BB}$ dan $400 \mathrm{mg} / \mathrm{Kg}$ $\mathrm{BB}$ yang menandakan bahwa semua hewan uji dalam keadaan yang sama.

Hasil pengukuran kadar glukosa darah pada hari ke-35 untuk kelompok kontrol normal, kontrol negatif, kontrol positif (metformin), kelompok dosis 100 $\mathrm{mg} / \mathrm{Kg} \mathrm{BB}, 200 \mathrm{mg} / \mathrm{Kg}$ BB dan $400 \mathrm{mg} / \mathrm{Kg}$ BB berturut-turut adalah 98,6; 402,4; 315,8; 350,$6 ; 365$ dan 368. Hal ini menunjukan bahwa semua kelompok hewan uji telah mengalami hiperglikemia yang ditandai dengan kadar glukosa darah $>200 \mathrm{mg} / \mathrm{dL}$, kecuali kontrol normal karena tidak diberikan pakan tinggi lemak dan diinduksi streptozotocin.

Hasil statistik One Way Anova pada hari ke-35 memperlihatkan nilai $\mathrm{P}=0,000$ $(\mathrm{P}<0,05)$ yang menunjukkan terdapat perbedaan yang signifikan pada semua kelompok perlakuan, yang artinya ada efek pemberian streptozotocin kecuali pada kontrol normal, sehingga dilanjutkan dengan uji post hoc LSD untuk melihat perbedaan yang bermakna antar kelompok perlakuan. Hasil uji lanjut post hoc LSD menunjukkan bahwa kontrol normal berbeda signifikan dengan semua kelompok, sedangkan kontrol negatif tidak berbeda signifikan dengan kelompok dosis $100 \mathrm{mg} / \mathrm{Kg} \mathrm{BB}, 200 \mathrm{mg} / \mathrm{kg} \mathrm{BB}$ dan 400 $\mathrm{mg} / \mathrm{kg} \mathrm{BB}$ tetapi berbeda signifikan dengan kontrol normal dan kontrol positif. Kontrol positif berbeda signifikan dengan dengan kontrol normal, kontrol negatif dan kelompok dosis $100 \mathrm{mg} / \mathrm{Kg}$ BB tetapi tidak berbeda signifikan dengan kelompok dosis $200 \mathrm{mg} / \mathrm{Kg}$ BB dan $400 \mathrm{mg} / \mathrm{Kg}$ BB. Perbedaan ini disebabkan karena kondisi fisiologi dari hewan uji berbeda-beda dalam memberikan respon peningkatan kadar glukosa darah setelah induksi streptozotocin dosis $30 \mathrm{mg} / \mathrm{Kg} \mathrm{BB}$.

Hasil pengukuran kadar glukosa darah pada hari ke-42 untuk kelompok kontrol normal, kontrol negatif, kontrol positif (metformin), kelompok dosis 100 $\mathrm{mg} / \mathrm{Kg} \mathrm{BB}, 200 \mathrm{mg} / \mathrm{Kg}$ BB dan $400 \mathrm{mg} / \mathrm{Kg}$ BB berturut-turut adalah 99,6; 398,4; 117; 146,8; 136,6 dan 134.4. Hal ini menunjukan adanya penurunan kadar glukosa darah pada kontrol positif (metformin), kelompok dosis $100 \mathrm{mg} / \mathrm{kg} \mathrm{BB}, 200 \mathrm{mg} / \mathrm{kg}$ BB dan $400 \mathrm{mg} / \mathrm{kg} \mathrm{BB}$.

Hasil statistik One Way Anova pada hari ke-42 memperlihatkan nilai $\mathrm{P}=0,000$ $(\mathrm{P}<0,05)$ yang menunjukkan terdapat perbedaan yang signifikan pada semua kelompok perlakuan, yang artinya ada efek pemberian kontrol positif (metformin) maupun ekstrak dosis $100 \mathrm{mg} / \mathrm{Kg} \mathrm{BB}, 200$ $\mathrm{mg} / \mathrm{kg} \mathrm{BB}$ dan $400 \mathrm{mg} / \mathrm{Kg} \mathrm{BB}$, sehingga dilanjutkan dengan uji post hoc LSD untuk melihat perbedaan yang bermakna antar kelompok perlakuan. Hasil uji lanjut post hoc LSD menunjukkan bahwa kontrol normal tidak berbeda signifikan dengan kontrol positif, tetapi berbeda signifikan kontrol negatif, kelompok dosis $100 \mathrm{mg} / \mathrm{Kg}$ $\mathrm{BB}, 200 \mathrm{mg} / \mathrm{Kg}$ BB dan $400 \mathrm{mg} / \mathrm{Kg} \mathrm{BB}$. Hal ini menunjukan bahwa kadar glukosa darah kontrol positif (metformin) mengalami penurunan mendekati kadar glukosa darah normal. Kontrol negatif berbeda signifikan dengan semua kelompok perlakuan. Hal ini disebabkan karena pada kontrol negatif tidak diberikan pelakuan apapun. Kontrol positif tidak berbeda signifikan dengan kontrol normal, kelompok dosis $200 \mathrm{mg} / \mathrm{Kg} \mathrm{BB}$ dan 400 $\mathrm{mg} / \mathrm{Kg} \quad \mathrm{BB}$ namun berbeda signifikan dengan kontrol negatif dan kelompok dosis $100 \mathrm{mg} / \mathrm{kg}$ BB. Hal ini menunjukkan bahwa kelompok dosis $200 \mathrm{mg} / \mathrm{Kg}$ BB dan 400 $\mathrm{mg} / \mathrm{Kg} \mathrm{BB}$ sudah dapat memberikan efek sebanding dengan kontrol positif (metformin), sedangkan kelompok dosis $100 \mathrm{mg} / \mathrm{Kg}$ BB belum dapat memberikan efek penurunan kadar glukosa darah sebanding dengan kontrol positif. Perbedaan yang dihasilkan oleh kelompok dosis $100 \mathrm{mg} / \mathrm{Kg} \mathrm{BB}, 200 \mathrm{mg} / \mathrm{Kg}$ BB dan 
Uji Efek Ekstrak Etanol Daun Sukun (Artocarpus altilis (Parkinson Ex F.A.Zorn) terhadap Penurunan Kadar Glukosa Darah, Kolesterol Total dan Gambaran Histopatologi Pankreas Tikus Putih Jantan (Rattus norvegicus) Hiperkolesterolemia-Diabetes

$400 \mathrm{mg} / \mathrm{Kg} \mathrm{BB}$ dalam menurunkan kadar glukosa dalam darah disebabkan karena kondisi fisiologi hewan uji berbeda-beda dalam memberikan respon penurunan kadar glukosa darah.

Hasil pengukuran kadar glukosa darah pada hari ke-49 untuk kelompok kontrol normal, kontrol negatif, kontrol positif (metformin), kelompok dosis 100 $\mathrm{mg} / \mathrm{Kg} \mathrm{BB}, 200 \mathrm{mg} / \mathrm{Kg} \mathrm{BB}$ dan $400 \mathrm{mg} / \mathrm{Kg}$ BB berturut-turut adalah 96,8; 360,6; 106,4; 119,$8 ; 108,4$ dan 110,4. Hal ini menunjukan bahwa adanya penurunan kadar glukosa darah pada kelompok dosis $100 \mathrm{mg} / \mathrm{Kg} \mathrm{BB}$, $200 \mathrm{mg} / \mathrm{Kg}$ BB dan $400 \mathrm{mg} / \mathrm{Kg} \quad \mathrm{BB}$ sebanding kontrol positif dan mendekati kontrol normal.

Hasil statistik One Way Anova pada hari ke-49 memperlihatkan nilai $\mathrm{P}=0,000$ $(\mathrm{P}<0,05)$ yang menunjukkan terdapat perbedaan yang signifikan pada semua kelompok perlakuan, yang artinya ada efek pemberian kontrol positif metformin maupun ekstrak dosis $100 \mathrm{mg} / \mathrm{Kg} \mathrm{BB}, 200$ $\mathrm{mg} / \mathrm{Kg} \mathrm{BB}$ dan $400 \mathrm{mg} / \mathrm{Kg} \mathrm{BB}$, sehingga dilanjutkan dengan uji post hoc LSD untuk melihat perbedaan yang bermakna antar kelompok perlakuan. Hasil uji lanjut post hoc LSD menunjukkan bahwa kontrol negatif berbeda signifikan dengan semua kelompok perlakuan, sedangkan kontrol normal berbeda signifikan dengan kontrol negatif, tetapi tidak berbeda signifikan kontrol positif dan kelompok dosis 100 $\mathrm{mg} / \mathrm{Kg} \mathrm{BB}, 200 \mathrm{mg} / \mathrm{Kg}$ BB dan $400 \mathrm{mg} / \mathrm{Kg}$ BB. Hal ini menunjukkan bahwa kadar glukosa darah hewan uji pada hari ke-49 untuk kontrol positif mengalami penurunan yang baik. Kontrol positif berbeda signifikan dengan kontrol negatif tetapi tidak berbeda signifikan dengan kontrol normal dan kelompok dosis $100 \mathrm{mg} / \mathrm{Kg} \mathrm{BB}$, $200 \mathrm{mg} / \mathrm{Kg}$ BB dan $400 \mathrm{mg} / \mathrm{Kg} \mathrm{BB}$. Hal ini menunjukkan bahawa semua kelompok dosis sudah mampu menurunkan kadar glukosa darah hewan uji yang baik dan sebanding dengan penurunan pada kontrol positif dan mendekati kadar glukosa darah normal.

Dosis efektif adalah $200 \mathrm{mg} / \mathrm{Kg} \mathrm{BB}$, karena dosis $200 \mathrm{mg} / \mathrm{Kg} \mathrm{BB}$ memberikan efek menurunkan kadar glukosa darah yang sebanding dengan kontrol positif dan mendekati kadar glukosa darah normal.

Hasil statistik One Way Anova pada hari ke-0 memperlihatkan nilai $\mathrm{P}=0,399$ $(\mathrm{P}>0,05)$ yang menunjukkan tidak terdapat perbedaan yang signifikan pada semua kelompok perlakuan yaitu kontrol normal, kontrol negatif, kontrol positif, dosis 100 $\mathrm{mg} / \mathrm{Kg} \mathrm{BB}, 200 \mathrm{mg} / \mathrm{Kg} \mathrm{BB}$ dan $400 \mathrm{mg} / \mathrm{Kg}$ $\mathrm{BB}$ yang menandakan bahwa semua hewan uji dalam keadaan yang sama.

Hasil pengukuran kadar kolesterol pada hari ke-35 untuk kelompok kontrol normal, kontrol negatif, kontrol positif (sinvastatin), kelompok dosis $100 \mathrm{mg} / \mathrm{Kg}$ $\mathrm{BB}, 200 \mathrm{mg} / \mathrm{Kg} \mathrm{BB}$ dan $400 \mathrm{mg} / \mathrm{Kg} \mathrm{BB}$ berturut-turut adalah 108,$6 ; 280,2 ; 271$; $273 ; 269,6$ dan 269,4. Hal ini menunjukan bahwa semua kelompok hewan uji telah mengalami hiperkolesterolemia yang ditandai dengan kadar kolesterol >200 mg/dL, kecuali kontrol normal karena tidak diberikan pakan tinggi lemak dan diinduksi streptozotocin.

Hasil statistik One Way Anova pada hari ke-35 memperlihatkan nilai $\mathrm{P}=0,000$ $(\mathrm{P}<0,05)$ yang menunjukkan terdapat perbedaan yang signifikan pada semua kelompok perlakuan, yang artinya ada efek pemberian pakan tinggi lemak dan induksi streptozotocin kecuali pada kontrol normal, sehingga dilanjutkan dengan uji post hoc LSD untuk melihat perbedaan yang bermakna antar kelompok perlakuan. Hasil uji lanjut post hoc LSD menunjukkan bahwa kontrol normal berbeda signifikan dengan semua kelompok, sedangkan kontrol negatif tidak berbeda signifikan dengan kelompok dosis $100 \mathrm{mg} / \mathrm{Kg} \mathrm{BB}$, $200 \mathrm{mg} / \mathrm{kg} \mathrm{BB}, 400 \mathrm{mg} / \mathrm{kg}$ BB dan kontrol positif tetapi berbeda signifikan dengan kontrol normal. Kontrol positif berbeda 
Uji Efek Ekstrak Etanol Daun Sukun (Artocarpus altilis (Parkinson Ex F.A.Zorn) terhadap Penurunan Kadar Glukosa Darah, Kolesterol Total dan Gambaran Histopatologi Pankreas Tikus Putih Jantan (Rattus norvegicus) Hiperkolesterolemia-Diabetes

signifikan dengan dengan kontrol normal, tetapi tidak berbeda signifikan dengan kontrol negatif, kelompok dosis $100 \mathrm{mg} / \mathrm{Kg}$ $\mathrm{BB}$, dosis $200 \mathrm{mg} / \mathrm{Kg} \mathrm{BB}$ dan dosis 400 $\mathrm{mg} / \mathrm{Kg}$ BB. Perbedaan ini disebabkan karena kondisi fisiologi dari hewan uji berbeda-beda dalam memberikan respon peningkatan kadar kolesterol setelah pemberian pakan tinggi lemak induksi streptozotocin.

Hasil pengukuran kadar kolesterol pada hari ke-42 untuk kelompok kontrol normal, kontrol negatif, kontrol positif (sinvastatin), kelompok dosis $100 \mathrm{mg} / \mathrm{Kg}$ $\mathrm{BB}, 200 \mathrm{mg} / \mathrm{Kg} \mathrm{BB}$ dan $400 \mathrm{mg} / \mathrm{Kg} \mathrm{BB}$ berturut-turut adalah 109,4; 273; 203,8; 223,2; 211 dan 231.2. Hal ini menunjukan adanya penurunan kadar kolesterol pada kontrol positif (sinvastatin), kelompok dosis $100 \mathrm{mg} / \mathrm{kg} \mathrm{BB}, 200 \mathrm{mg} / \mathrm{kg}$ BB dan 400 $\mathrm{mg} / \mathrm{kg} \mathrm{BB}$.

Hasil statistik One Way Anova pada hari ke-42 memperlihatkan nilai $\mathrm{P}=0,000$ $(\mathrm{P}<0,05)$ yang menunjukkan terdapat perbedaan yang signifikan pada semua kelompok perlakuan, yang artinya ada efek pemberian kontrol positif (sinvastatin) maupun ekstrak dosis $100 \mathrm{mg} / \mathrm{Kg} \mathrm{BB}, 200$ $\mathrm{mg} / \mathrm{kg} \mathrm{BB}$ dan $400 \mathrm{mg} / \mathrm{Kg} \mathrm{BB}$, sehingga dilanjutkan dengan uji post hoc LSD untuk melihat perbedaan yang bermakna antar kelompok perlakuan. Hasil uji lanjut post hoc LSD menunjukkan bahwa kontrol normal dan kontrol negatif berbeda signifikan dengan semua kelompok, sedangkan kontrol positif berbeda signifikan dengan kontrol normal, kontrol negatif dan kelompok dosis $100 \mathrm{mg} / \mathrm{Kg} \mathrm{BB}$ dan $400 \mathrm{mg} / \mathrm{Kg}$ BB tetapi tidak berbeda signifikan dengan kelompok dosis 200 $\mathrm{mg} / \mathrm{Kg} \mathrm{BB}$. Hal ini menunjukkan bahwa kelompok dosis $200 \mathrm{mg} / \mathrm{Kg}$ BB sudah dapat memberikan efek sebanding dengan kontrol positif (sinvastatin), sedangkan kelompok dosis $100 \mathrm{mg} / \mathrm{Kg}$ BB dan $400 \mathrm{mg} / \mathrm{Kg} \mathrm{BB}$ belum dapat memberikan efek penurunan kadar kolesterol sebanding dengan kontrol positif. Perbedaan yang dihasilkan oleh kelompok dosis $100 \mathrm{mg} / \mathrm{Kg} \mathrm{BB}, 200 \mathrm{mg} / \mathrm{Kg}$ $\mathrm{BB}$ dan $400 \mathrm{mg} / \mathrm{Kg} \mathrm{BB}$ dalam menurunkan kadar kolesterol disebabkan kandungan zat aktif pada daun sukun berbeda ataupun disebabkan kondisi fisiologi dari hewan uji berbeda dalam memberikan respon penurunan kadar kolesterol setelah pemberian pakan tinggi lemak induksi streptozotocin.

Hasil pengukuran kadar kolesterol pada hari ke-49 untuk kelompok kontrol normal, kontrol negatif, kontrol positif (sinvastatin), kelompok dosis $100 \mathrm{mg} / \mathrm{Kg}$ $\mathrm{BB}, 200 \mathrm{mg} / \mathrm{Kg} \mathrm{BB}$ dan $400 \mathrm{mg} / \mathrm{Kg} \mathrm{BB}$ berturut-turut adalah 111,2; 265; 173,6; 198,2; 181,8; dan 213. Hal ini menunjukan bahwa adanya penurunan kadar kolesterol pada kelompok dosis $100 \mathrm{mg} / \mathrm{Kg} \mathrm{BB}, 200$ $\mathrm{mg} / \mathrm{Kg} \mathrm{BB}$ dan $400 \mathrm{mg} / \mathrm{Kg} \mathrm{BB}$ sebanding kontrol positif dan mendekati kontrol normal.

Hasil statistik One Way Anova pada hari ke-49 memperlihatkan nilai $\mathrm{P}=0,000$ $(\mathrm{P}<0,05)$ yang menunjukkan terdapat perbedaan yang signifikan pada semua kelompok perlakuan, yang artinya ada efek pemberian kontrol positif (sinvastatin) maupun ekstrak dosis $100 \mathrm{mg} / \mathrm{Kg} \mathrm{BB}, 200$ $\mathrm{mg} / \mathrm{Kg} \mathrm{BB}$ dan $400 \mathrm{mg} / \mathrm{Kg} \mathrm{BB}$, sehingga dilanjutkan dengan uji post hoc LSD untuk melihat perbedaan yang bermakna antar kelompok perlakuan. Hasil uji lanjut post hoc LSD menunjukkan bahwa kontrol normal dan kontrol negatif berbeda signifikan dengan semua kelompok, sedangkan kontrol positif berbeda signifikan dengan kontrol normal, kontrol negatif dan kelompok dosis $100 \mathrm{mg} / \mathrm{Kg} \mathrm{BB}$ dan $400 \mathrm{mg} / \mathrm{Kg}$ BB tetapi tidak berbeda signifikan dengan kelompok dosis 200 $\mathrm{mg} / \mathrm{Kg} \mathrm{BB}$. Hal ini menunjukkan bahwa kelompok dosis $200 \mathrm{mg} / \mathrm{Kg}$ BB sudah dapat memberikan efek sebanding dengan kontrol positif (sinvastatin), Hal ini disebabkan dosis $200 \mathrm{mg} / \mathrm{Kg} \mathrm{BB}$ merupakan dosis yang sesuai sehingga ekstrak dapat terpenetrasi 
Uji Efek Ekstrak Etanol Daun Sukun (Artocarpus altilis (Parkinson Ex F.A.Zorn) terhadap Penurunan Kadar Glukosa Darah, Kolesterol Total dan Gambaran Histopatologi Pankreas Tikus Putih Jantan (Rattus norvegicus) Hiperkolesterolemia-Diabetes

sempurna didalam tubuh dan sudah mampu berikatan dengan reseptornya dan dosis daun sukun yang tidak terlalu pekat sehingga membuat ekstrak daun sukun terabsorpsi dengan baik sehingga senyawa kimia yang terkandung dapat mencapai reseptornya. Sedangkan kelompok dosis $100 \mathrm{mg} / \mathrm{Kg} \mathrm{BB}$ dan $400 \mathrm{mg} / \mathrm{Kg}$ BB belum dapat memberikan efek penurunan kadar kolesterol sebanding dengan kontrol positif. Perbedaan yang dihasilkan oleh kelompok dosis $100 \mathrm{mg} / \mathrm{Kg} \mathrm{BB}, 200 \mathrm{mg} / \mathrm{Kg}$ BB dan $400 \mathrm{mg} / \mathrm{Kg} \mathrm{BB}$ dalam menurunkan kadar kolesterol disebabkan kandungan zat aktif pada daun sukun berbeda ataupun disebabkan kondisi fisiologi dari hewan uji berbeda-beda dalam memberikan respon penurunan kadar kolesterol setelah pemberian pakan tinggi lemak induksi streptozotocin.

Kelompok perlakuan ekstrak daun sukun dengan variasi dosis $100 \mathrm{mg} / \mathrm{Kg} \mathrm{BB}$, $200 \mathrm{mg} / \mathrm{Kg}$ BB dan $400 \mathrm{mg} / \mathrm{Kg} \quad \mathrm{BB}$ memiliki efek dalam menurunkan kadar kolesterol. Dosis efektif adalah $200 \mathrm{mg} / \mathrm{Kg}$ $\mathrm{BB}$, karena dosis $200 \mathrm{mg} / \mathrm{Kg} \quad \mathrm{BB}$ memberikan efek menurunkan kadar glukosa darah sebanding dengan kontrol positif (simvastatin) dan mendekati kadar kolesterol normal.

Hasil statistik non parametric dengan uji kruskal wallis menunjukan adanya perbedaan signifikan antar kelompok perlakuan. Hal tersebut dapat dibuktikan dengan melihat nilai signifikansi $\mathrm{P}=0.001$ $(\mathrm{P}<0,05)$ yang artinya terdapat perbedaan dari tiap kelompok, dan digunakan uji manwhitney untuk mengetahui perbedaan pada tiap pelakuan.

Pengujian man-whitney kelompok dosis $100 \mathrm{mg} / \mathrm{Kg}$ BB berbeda signfikan terhadap kelompok normal, kelompok negatif, kelompok dosis $400 \mathrm{mg} / \mathrm{Kg} \mathrm{BB}$ $(\mathrm{p}<0,05)$, tetapi tidak berbeda signifikan terhadap kelompok positif dan kelompok dosis $200 \mathrm{mg} / \mathrm{Kg}$ BB ( $>0,05)$. Pengujian man-whitney kelompok dosis $200 \mathrm{mg} / \mathrm{Kg}$
BB berbeda signfikan terhadap kelompok normal, kelompok negatif dan kelompok dosis $400 \mathrm{mg} / \mathrm{Kg}$ BB $(\mathrm{p}<0,05)$, tetapi tidak berbeda signifikan terhadap, kelompok positif, kelompok dosis $100 \mathrm{mg} / \mathrm{Kg}$ BB $(\mathrm{p}>0,05)$. Pengujian man-whitney dosis $400 \mathrm{mg} / \mathrm{Kg}$ BB berbeda signfikan terhadap kelompok normal, kelompok positif, kelompok dosis $100 \mathrm{mg} / \mathrm{Kg}$ BB dan kelompok dosis $200 \mathrm{mg} / \mathrm{Kg}$ BB $(\mathrm{p}<0,05)$, tetapi tidak berbeda signifikan terhadap kelompok negatif $(\mathrm{p}>0,05)$.

Berdasarkan hasil pengamatan preparat histopatologi pankreas tikus dan statistik yang dilakukan, maka dapat diketahui bahwa ekstrak daun sukun memiliki efek terhadap regenerasi jaringan pankreas, dimana dalam dosis $100 \mathrm{mg} / \mathrm{Kg}$ $\mathrm{BB}, 200 \mathrm{mg} / \mathrm{Kg}$ BB $400 \mathrm{mg} / \mathrm{Kg}$ BB sudah efektif terhadap regenerasi jaringan pankreas tetapi pada dosis $400 \mathrm{mg} / \mathrm{Kg} \mathrm{BB}$ mempunyai efek yang lebih baik dari dosis $200 \mathrm{mg} / \mathrm{Kg}$ BB sedangkan ekstrak etanol daun sukun dosis $100 \mathrm{mg} / \mathrm{Kg}$ BB tidak memberikan efek yang maksimal, hal ini terjadi akibat tingginya konsentrasi ekstrak yang membuat menurunnya penyerapan sehingga tidak terabsorpsi dengan baik.

Efek penurunan kadar glukosa darah, kadar kolesterol, dan perbaikan pulau langerhans disebabkan adanya kandungan senyawa bioaktif yang terkandung dalam ekstrak etanol daun sukun, yaitu flavonoid yang berperan sebagai antioksidan sehingga dapat menghambat pembentukan radikal bebas dengan menetralisir peningkatan Reactive Oxygen Species (ROS) akibat diabetes dan mampu meregenerasi sel-sel $\beta$ pankreas yang rusak sehingga defisiensi insulin dapat diatasi (Suhardinata F, 2015). Polifenol bersifat sebagai antioksidan dapat menstabilkan radikal bebas dengan melengkapi kekurangan elektron yang dimiliki radikal bebas dan menghambat terjadinya reaksi berantai dari pembentukan radikal bebas (Silalahi R.M, 2010). Saponin dapat menurunkan kadar glukosa darah 
Uji Efek Ekstrak Etanol Daun Sukun (Artocarpus altilis (Parkinson Ex F.A.Zorn) terhadap Penurunan Kadar Glukosa Darah, Kolesterol Total dan Gambaran Histopatologi Pankreas Tikus Putih Jantan (Rattus norvegicus) Hiperkolesterolemia-Diabetes

dengan cara menghambat transport glukosa di dalam saluran cerna dan merangsang sekresi insulin pada sel beta pankreas (Andrie M, 2014). Alkaloid dapat bekerja dengan menurunkan glukoneogenesis sehingga kadar glukosa dalam tubuh dan kebutuhan insulin menurun (Andrie M, 2014). Tanin juga mempunyai aktivitas hipoglikemik yaitu dengan meningkatkan glikogenesis dan berfungsi sebagai astringent atau pengkelat yang dapat mengerutkan membran epitel usus halus sehingga mengurangi penyerapan sari makanan dan sebagai akibatnya menghambat asupan glukosa dan laju peningkatan glukosa darah tidak terlalu tinggi (Prameswari, 2014).

\section{KESIMPULAN}

Berdasarkan hasil penelitian maka dapat disimpulkan bahwa :

1. Ekstrak etanol daun sukun (Artocarpus altilis (Parkinson Ex F.A.Zorn) mengandung senyawa metabolit sekunder berupa, Alkaloid, Flavonid, Saponin, Tanin, dan polifenol.

2. Ekstrak etanol daun sukun (Artocarpus altilis (Parkinson Ex F.A.Zorn) memiliki efek dalam menurunkan kadar glukosa darah, kolesterol, dan perbaikan pulau langerhans tikus putih jantan Hiperkolesterolemia-Diabetes.

3. Ekstrak etanol daun sukun dosis 200 $\mathrm{mg} / \mathrm{kg}$ BB merupakan dosis yang efektif dalam menurunkan kadar glukosa darah dan kolesterol pada tikus putih jantan hiperkolesterolemia-diabetes, ekstrak etanol daun sukun dosis $400 \mathrm{mg} / \mathrm{kg}$ BB efektif memperbaiki pulau langerhans pada tikus putih jantan hiperkolesterolemia-diabetes.

\section{DAFTAR PUSTAKA}

[1]. Chairunnisa R. 2012. Pengaruh Jumlah Pasta Tomat Terhadap Penurunan Kadar Gula darah Pada Mencit Diabetes. Fakultas teknologi industri pertanian. Pasca Sarjana. UNAND. Padang. Hal 2

[2]. Intanowa, Agustina. 2012. Efek Estrak Ethanol Daun Sukun terhadap Kadar Gula Darah pada Tikus Putih Diabetes Melitus yang di Induksi dengan Alloxan. Program Studi Ilmu Keperawatan Fakultas Kedokteran-Udayana.

[3]. Kannon, M Q. 2011. Uji Efektivitas Ekstrak Kulit Buah Salak (Salacca Zalacca (Gaertn.) Voss) Terhadap Penurunan Kadar Gula Darah Tikus Putih Jantan Galur Wistar (Rattus Norvegicus) Yang Diinduksi Sukrosa. Jurnal Ilmiah. UNSTRAD Manado. Hal 54

[4]. Kusumawati, D. 2004. Bersahabat dengan Hewan Coba. Gajahmada University Pers. Yogyakarta. Hal 34-35

[5]. Marianne, Yuandani, Rosnani. 2011. Antidiabetic Activity From Ethanol Extract Of Kluwih's Leaf (Artocarpus Camansi). Vol. 11, No.2 Fakultas Farmasi. Universitas Sumatera Utara. Hal 64.

[6]. Nurdiana, P,N. Setyawati, M,A. 1998. Efek Streptozotocin sebagai Bahan Diabetogenik pada Tikus Wistar dengan Cara Pemberian Intraperitonial dan Intravena. Malang. Majalah Kedokteran Unibraw. Vol. XIV, Hal 67

[7]. Puersul, Irwanto., Supryatna, Agus. 2007. Perbedaan Khasiat Obat-obatan Kimia Dan Obat-obatan Alami. Departemen Kesehatan Indonesia. Jurusan Farmasi. 